\title{
Kandungan Proksimat dan Mineral dari Keong Mata Lembu (Turbo setosus Gmelin 1791)
}

\section{Proximate and Mineral Composition of The Rough Turban Snails (Turbo setosus Gmelin 1791)}

\author{
Dewi Merdekawati ${ }^{1}$, Tati Nurhayati ${ }^{2}$, Agoes M Jacoeb ${ }^{2}$ \\ ${ }^{1}$ Dosen Faperta UNIDA \\ 2 Dosen Departemen Teknologi Hasil Perairan FPIK IPB
}

Email: dewhi.08@gmail.com

\begin{abstract}
The rough turban snails (Turbo setosus) were potential as a source of protein and minerals that serve as aphrodisiacs and antioxidants such as $\mathrm{K}, \mathrm{Mg}, \mathrm{Ca}, \mathrm{Fe}, \mathrm{Zn}$, and $\mathrm{Cu}$. The objective of this research is to know the handling, processing, and chemical compound of the rough turban snails. Harvesting and handling of these snails still modest. The composition of dried rough turban snails was protein $70,34 \%$, fat $2,20 \%$, ash $6,87 \%$, carbohydrate $10,06 \%$ and moisture $10,15 \%$. The highest macro mineral content is potassium of $8225.29 \mathrm{ppm}$ while for the highest micro mineral is iron $98.68 \mathrm{ppm}$.
\end{abstract}

Keywords: Mineral composition, proximate, Turbo setosus

\section{ABSTRAK}

Keong mata lembu ( $T$. setosus) memiliki potensi sebagai sumber protein dan mineral yang berfungsi sebagai aprodisiak seperti $\mathrm{K}, \mathrm{Mg}, \mathrm{Ca}, \mathrm{Fe}, \mathrm{Zn}$, dan $\mathrm{Cu}$. Penelitian bertujuan untuk mengetahui penanganan, pengolahan, dan komposisi kimia keong mata lembu. Cara panen dan penanganan keong ini masih sangat sederhana. Hasil analisis proksimat adalah $70,34 \%$ protein, 2,20\% lemak, 6,87\% abu, 10,06\% karbohidrat, dan 10,15\% air. Kandungan mineral makro tertinggi adalah kalium sebesar 8225,29 ppm sedangkan untuk mineral mikro tertinggi adalah sebesar 98,68 ppm.

Kata Kunci: kandungan mineral, proksimat,Turbo setosus

Dewi Merdekawati, Tati Nurhayati dan Agoes M Jacoeb. 2017. Kandungan Mineral dan Proksimat Keong Mata Lembu (Turbo setosus Gmelin 1791). Jurnal Mina Sains 3(1): 47-53.

\section{PENDAHULUAN}

Sekitar 55.000 jenis gastropoda menempati habitat laut dan tersebar dari pantai hingga ke laut dalam yang berpotensi besar untuk diaplikasikan di bidang pangan, obatobatan dan bioteknologi (Fahmi et al. 2012). Komposisi kimia dari daging gastropoda dipengaruhi oleh jenis, spesies, ukuran (umur), tingkat kematangan seksual, suhu, jenis makanan, lokasi, dan musim (Periyasamy et al. 2011).

Keong sudah dikonsumsi oleh manusia sebagai makanan dan di banyak negara Eropa terutama Prancis, dimana keong dikonsumsi dalam jumlah besar (Milinsk et al. 2003). Demikian pula banyak negara-negara Asia misalnya Korea dan Jepang yang menangkap keong untuk dikonsumsi dan dagingnya dianggap lezat (Qun et al. 2004; Xie et al. 2007).

Turbo setosus termasuk dalam ordo Archaeogastropoda. Habitat keong ini adalah pecahan batu karang, dan pasir karang pada dataran terumbu karang, dataran karang mati ditumbuhi Sargassum sp. (Soekendarsi 2004).

Keong mata lembu mempunyai nilai ekonomi bagi penduduk disekitar Perairan 
Ujung Genteng, keberadaannya cukup melimpah, harga relatif murah dan digunakan sebagai bahan pangan. Keong ini diperdagangkan dalam bentuk segar, rebus, dan sate. Secara empiris dipercaya memiliki khasiat untuk meningkatkan stamina dan vitalitas (aprodisiak). Daging keong ini diduga mengandung komponen-komponen bioaktif Namun informasi mengenai kandungan gizinya belum tersedia. Penelitian ini bertujuan untuk mengetahui penanganan dan pengolahan serta komposisi kimia keong mata lembu.

\section{Bahan}

\section{BAHAN DAN METODE}

Bahan utama penelitian ini adalah keong mata lembu yang didapat dari Perairan Ujung Genteng Kabupaten Sukabumi Jawa Barat. Daging dikeringkan selama 33 jam dengan suhu $50-60{ }^{\circ} \mathrm{C}$ dengan oven.

\section{Metode penelitian}

Untuk penanganan dan pengolahan diadakan survei ke habitat (Perairan Ujung Genteng) maupun di pasar. Analisis laboratorium dengan metode: proksimat (AOAC 2005) dan mineral dengan AAS (Atomis Absorption Spectrophotometry).

\section{HASIL DAN PEMBAHASAN}

Penanganan dan Pengolahan

Cara mengetahui lokasi keong saat surut sangat mudah karena terlihat, tetapi saat pasang keong tidak tampak, sehingga diperlukan keahlian khusus untuk mengetahui keberadaan keong. Habitat dari keong ini yaitu di sekitar pecahan batu karang, maka pengambilannya harus berhati-hati. Untuk mendapatkannya, penangkapan harus dilakukan malam hari. Saat gelap, keong ini berkeliaran di seputar karang hingga ke bibir pantai, sehingga mudah untuk dicari.

Pengolahan di masyarakat sebelum dikonsumsi cukup mudah. Keong direbus dalam air bergaram atau direndam dalam cuka dan jeruk nipis supaya bau amisnya hilang selama hampir 15-30 menit. Pengambilan daging dari cangkangnya yaitu dengan memukulkannya ke kayu atau batu pipih dengan arah cangkang miring. Setelah rongga terbuka sedikit maka daging keong juga ikut tertarik ke luar dan keong siap dikonsumsi. Pengolahan dan penanganan dipaparkan pada Gambar 1.

\section{Analisis Proksimat}

Kandungan gizi daging keong mata lembu dan beberapa jenis gastropoda dan moluska lainnya disajikan pada Tabel 1 .

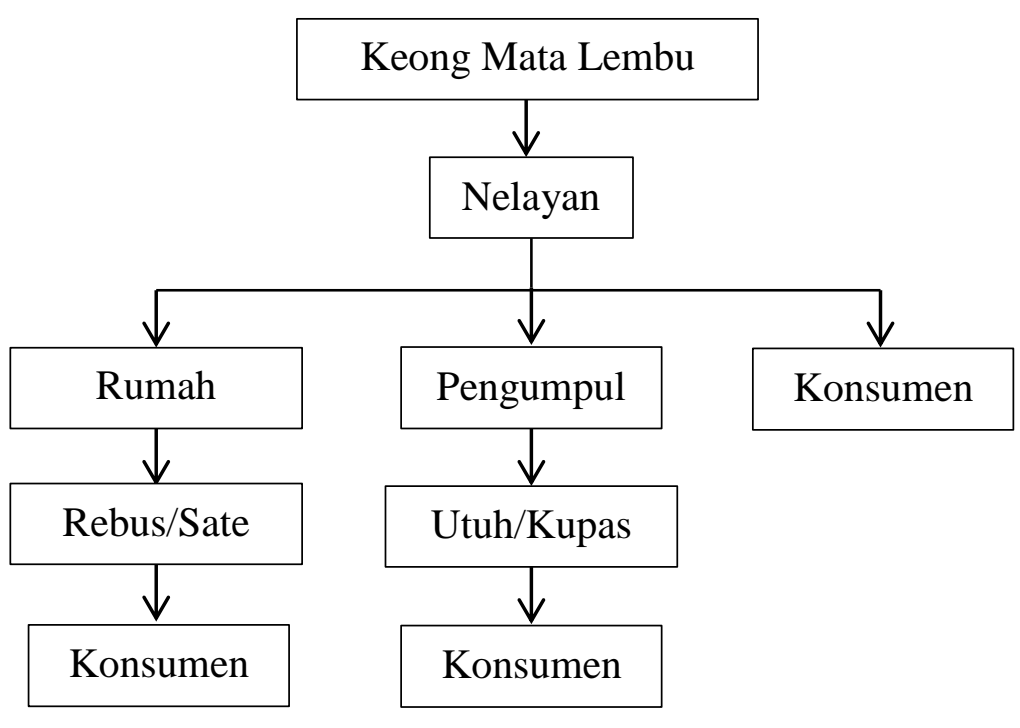

Garam 1 Diagram alir penanganan dan pengolahan keong mata lembu. 
Tabel 1 Hasil analisis proksimat daging yang telah dikeringkan dibandingkan dengan sumber nutrisi lain

\begin{tabular}{|c|c|c|c|c|c|c|}
\hline Parameter & $\begin{array}{c}\text { Keong Mata } \\
\text { Lembu } \\
\text { (Turbo } \\
\text { setosus) }\end{array}$ & $\begin{array}{l}\text { Kablang } \\
\text { (Nerita }^{\text {albicilla })^{\mathrm{a}}}\end{array}$ & $\begin{array}{c}\text { Kerang Mas } \\
\text { Ngur } \\
\text { (Atactodea } \\
\text { striata) })^{\mathbf{b}}\end{array}$ & $\begin{array}{c}\text { Kerang Pokea } \\
\text { (B. Violacea } \\
\text { celebensis }^{\text {Marten 1897) }}\end{array}$ & $\begin{array}{c}\text { Kerang } \\
\text { Darah } \\
\text { (Anadara }_{\text {granosa })}\end{array}$ & $\begin{array}{l}\text { Teripang } \\
\text { Batu } \\
(H . \\
\text { scabra })^{\mathrm{d}}\end{array}$ \\
\hline Protein & $70,34 \pm 0,13$ & 62,05 & 56,08 & 50,48 & 79,92 & 54,05 \\
\hline Lemak & $2,20 \pm 0,01$ & 5,58 & 5,95 & 6,86 & 6,78 & 6,30 \\
\hline $\mathrm{Abu}$ & $6,87 \pm 0,12$ & 9,17 & 7,88 & 10,67 & 5,64 & 28,02 \\
\hline Karbohidrat & $10,06 \pm 0,04$ & 4,16 & 21 & 29,13 & 1,34 & 1,29 \\
\hline Air & $10,15 \pm 0,69$ & 12,44 & 7,84 & 2,70 & 6,32 & 10,34 \\
\hline
\end{tabular}

Nilai ditunjukkan sebagai rata-rata \pm standar deviasi dengan pengujian dua kali ulangan

Sumber: a Anand et al. (2010)

b Waranmaselembun (2007)

c Yenni (2012)

d Witjaksono (2005)

Tabel 1 menunjukkan bahwa komposisi proksimat daging dapat dikategorikan sebagai hasil perikanan yang berprotein tinggi (lebih dari 50\%) dan tinggi karbohidrat (lebih dari 20\%) serta lemak rendah (dibawah 5\%) sehingga baik untuk dikonsumsi khususnya bagi penderita penyakit hati (Ademolu et al. 2004; Milinsk et al. 2003 dan Primadhani 2006). Kandungan gizinya setara dengan beberapa jenis moluska maupun echinodermata yang telah dikonsumsi dan secara empiris dipercaya sebagai aprodisiaka serta mampu mengobati berbagai penyakit (Witjaksono dan Nurjanah et al. 2005).

Hasil pengukuran kadar air sebesar $10,15 \%$. Hasil serupa juga dilaporkan oleh Ehigiator et al. (2012) pada Tympanotonus fuscatus sebesar 10,37\%. Hasil yang berbeda dilaporkan oleh Hafiluddin et al. (2011) pada Discodoris sp. sebesar $11,17 \%$ dan Bello (2013) pada Penaeus notialis sebesar 16,09\%. Menurut Bassey et al. (2011) pengetahuan tentang kadar air bahan pangan berfungsi sebagai indeks untuk menjaga kualitas, kerentanan terhadap infeksi, jamur, dan kadar air yang rendah dapat memperpanjang masa simpan dari spesies ini.

Kadar protein pada penelitian ini sebesar 70,34\%. Ehigiator et al. (2012) melaporkan nilai protein dari Tympanotonus fuscatus sebesar 68,46\%. Periyasamy et al. (2011) mendapatkan kandungan protein dari daging kering Babylonia spirata yaitu 53,86\%. Devanathan dan Srinivashan (2011) melaporkan nilai protein dari Babylonia spirata berkisar 48\%-68\%. Hasil penelitian Palpandi (2010) menjelaskan kandungan protein maksimum Cymbium melo yang ditemukan pada bagian mantel $(30,19 \%)$ dan minimum pada jaringan tubuh lainnya $(20,87 \%)$.

Kadar lemak sebesar 2,20\%. Hasil tersebut lebih kecil dibandingkan dengan kadar lemak pada spesies moluska lainnya. Faktor yang mempengaruhi besarnya kandungan lemak adalah spesies, kematangan gonadnya serta umur. Spesies yang telah matang gonad akan meningkatkan kandungan lemak pada spesies tersebut (Majewska et al. 2009) Bassey et al. (2011) melaporkan nilai kadar lemak pada Pomecia polludosa dan Ergeria radiata memiliki rata-rata $6,03-7,60 \%$. Kandungan lemaknya termasuk rendah dan dapat dikategorikan dalam tipe lemak rendah dan diindikasikan bahwa spesies ini tidak akan mudah menjadi tengik (Abulude et al. 2006).

Hasil pengukuran kadar karbohidrat sebesar 10,06\%. Periyasamy et al. (2011) melaporkan bahwa kandungan karbohidrat dari daging Babylonia spirata kering adalah 16,65\% dan Anand et al. (2010) menunjukkan bahwa kandungan karbohidrat dari daging Pleuroploca trapezium kering sebesar 4,307\%. Kandungan karbohidrat dalam moluska yang utama dari glikogen dan terjadinya perubahan karbohidrat mungkin karena akumulasi dan pemanfaatan glikogen pada tahap yang berbeda seperti tahap gametogenesis dan pemijahan (Anshari et al. 1981).

Kadar abu daging keong kering sebesar $6,87 \%$ lebih kecil dibandingkan dengan kadar abu dari Tympanotonus spp sebesar $10,50 \%$ (Adebayo-Tayo dan Ogunjabi 2008), kablang (Nerita albicilla) 9,17\% dan kerang mas ngur 
7,88\% (Royani et al. dan Waranmaselembun et al. 2007). Setiap organisme mempunyai kemampuan yang berbeda dalam mengabsorbsi dan mengeluarkan mineral sehingga hal ini dapat memberikan pengaruh terhadap besarnya kadar abu dalam masing-masing bahan.

\section{Analisis Mineral}

Hasil analisis mineral pada Turbo setosus dapat dilihat pada Tabel 2. Tabel 2 memperlihatkan kandungan mineral makro pada daging kering didominasi oleh kalium $(\mathrm{K})$ sebesar 8225,29 ppm. Natrium, kalium, kalsium, dan magnesium dimanfaatkan untuk penerus pesan pada sel saraf dan kontraksi otot. Menurut Ando et al. (2010) kalium dan natrium membantu menjaga tekanan osmotik dan keseimbangan asam basa. Kandungan kalium yang seimbang dalam darah bisa mencegah penyakit hipertensi.

Tabel 2 Kandungan mineral Turbo setosus

\begin{tabular}{lrcc}
\hline \multicolumn{1}{c}{ Parameter } & \multicolumn{1}{c}{ Kering } & Limicolaria aurora* & Pleuroploca trapezium ** \\
\hline Mineral makro & & & \\
Kalium (K) & $8225,29 \pm 241,73$ & 533 & 78,5 \\
Kalsium (Ca) & $4056,71 \pm 240,40$ & 401 & 8.09 \\
Magnesium (Mg) & $1987,29 \pm 65,47$ & 771 & 3,11 \\
\hline Mineral mikro & & & \\
Besi (Fe) & $98,68 \pm 4,41$ & $\sim$ & 0,025 \\
Seng (Zn) & $48,17 \pm 4,82$ & 259 & $\sim$ \\
Tembaga $(\mathrm{Cu})$ & $4,43 \pm 0,14$ & $\sim$ & $\sim$ \\
Selenium $(\mathrm{Se})$ & $<0,002 \pm 0,00$ & $\sim$ & $\sim$ \\
\hline
\end{tabular}

Nilai ditunjukkan sebagai rata-rata \pm standar deviasi dengan pengujian dua kali ulangan.

* : Udoh et al. 1995

** : Anand et al. 2010

$\sim$ : tidak tersedia

Kalsium dan magnesium merupakan makronutrien diperlukan oleh tubuh. Keong ini dapat menyediakan 4056,71 ppm kalsium dan 1987,29 ppm magnesium. Kalsium berfungsi untuk pembentukan tulang dan gigi khususnya pada saat masa pertumbuhan dan ibu hamil. Magnesium memegang peranan penting dalam lebih dari tiga ratus jenis enzim didalam tubuh.

Mineral mikro terbesar adalah unsur besi (Fe), yaitu mineral mikro yang paling banyak terdapat di dalam tubuh hewan. Kandungan besi pada daging kering yaitu 98,68 ppm. Besi berperan dalam beberapa fungsi esensial di dalam tubuh yaitu sebagai alat angkut oksigen dari paru-paru ke jaringan tubuh, elektron di dalam sel, dan sebagai bagian terpadu berbagai reaksi enzim di dalam jaringan tubuh, dan berfungsi pada proses respirasi sel (Ademolu et al. 2004; Fagbuaro et al. 2006). Angka kecukupan besi laki-laki adalah $13 \mathrm{mg} /$ hari dan wanita $26 \mathrm{mg} /$ hari (Almatsier 2003). Menurut Karppanen et al. (2005) kekurangan magnesium berakibat kurangnya nafsu makan, terjadinya gangguan pertumbuhan dan penyakit jantung pada manusia.
Kandungan zink didaging kering yaitu 98,68 ppm. Seng memegang peranan esensial dalam banyak fungsi tubuh yaitu dalam sistem kerja enzim dan hormone, pengembangan fungsi reproduksi laki-laki dan pembentukan sperma, serta detoksifikasi alkohol dan metabolism vitamin A. Seng juga berperan dalam fungsi kekebalan, yaitu dalam fungsi sel $\mathrm{T}$ dan pembentukan antibodi oleh sel $\mathrm{B}$. Kebutuhan harian yang disarankan untuk mengkonsumsi seng menurut NRC, USA adalah $15 \mathrm{mg}$ untuk orang dewasa (Almatsier 2003; Anand et al. 2010).

Mengatasi masalah infertile dan impotensi pada pria, mempercepat penyembuhan maag serta mengatasi masalah Alzheimer juga memerlukan peran seng (Zn). Mengingat seng berperan dalam reaksi-reaksi yang luas, maka kekurangan mineral ini akan berdampak besar jaringan tubuh terutama pada saat pertumbuhan.

Kandungan tembaga $(\mathrm{Cu})$ pada daging adalah 4,43 ppm. Tembaga banyak berinteraksi dengan seng, molibden, belerang dan vitamin $\mathrm{C}$ dalam melaksanakan fungsinya dalam tubuh. 
tembaga berperan sebagai bagian dari enzim dalam reaksi yang menggunakan oksigen dan radikal oksigen. Enzim memegang peranan dalam mencegah anemia (Arifin 2008).

Selenium adalah mineral mikro yang merupakan bagian esensial dari enzim glutation peroksidase. Selenium bersama vitamin $\mathrm{E}$ bekerja sama dalam perannya sebagai antioksidan. Selenium juga bagian kompleks dari asam amino RNA (Almatsier 2003; Muchtadi 2009).

Kandungan selenium pada daging kecil dari 0,002 ppm. Goguklu et al. (2004) menyatakan bahwa beberapa faktor berpengaruh terhadap keanekaragaman kandungan mineral yaitu umur, spesies, ukuran tubuh, habitat, dan kondisi lingkungan.

Moluska dapat mengakumulasi kontaminasi dari bahan kimia yang bersifat toksik $(\mathrm{Hg}, \mathrm{Pb}, \mathrm{Cd})$ yang dihasilkan dari kegiatan manusia atau berasal dari alam dan hal ini dapat merugikan bagi setiap manusia yang mengkonsumsinya. Logam berat ini bersifat non-biodegradable dan karena dapat terakumulasi dalam lingkungan dari waktu ke waktu dan dapat oleh jaringan hewan atau tumbuhan. Setelah penyerapan logam berat cenderung mengikat protein dan asam nukleat dan merusak fungsinya (Sloen et al. 2008).

Hasil analisis kandungan logam berat adalah $\mathrm{Pb}<0,01 \mathrm{ppm}, \mathrm{Cd}<0,001 \mathrm{ppm}$ dan $\mathrm{Hg}$ $<0,0002 \mathrm{ppm}$. Dari hasil dapat dilihat bahwa keong ini aman untuk dikonsumsi. Kandungan logam berat yang sangat kecil disebabkan oleh habitatnya yang berada jauh dari pusat industri dan kegiatan manusia. Menurut FAO (1992) untuk kandungan logam berat moluska yaitu $\mathrm{Pb}$ 0,5-6,0 ppm, Cd 0,05-5,5 ppm dan $\mathrm{Hg} 0,5$ ppm, menurut WHO (1989) yaitu $\mathrm{Pb} 2,0$ ppm, Cd 1,0 ppm dan $\mathrm{Hg}$ 0,5 ppm, menurut SNI 7387:2009 kandungan logam cemaran dalam ikan dan produk perikanan termasuk jenis moluska yaitu kadmium $1,0 \mathrm{mg} / \mathrm{kg}$, merkuri $1,0 \mathrm{mg} / \mathrm{kg}$, timbal $1,5 \mathrm{mg} / \mathrm{kg}$, dan arsen 1,0 $\mathrm{mg} / \mathrm{kg}$. Dari hasil dapat dinyatakan bahwa kandungan logam yg ditemukan masih diambang batas aman .

\section{Kesimpulan}

\section{KESIMPULAN DAN SARAN}

Penanganan yang dilakukan masih sederhana yaitu hanya mengumpulkan dengan cara menangkap dengan tangan dan dikumpulkan diatas perahu pada saat malam hari. Jika dilihat dari komposisi kandungan gizi dapat dikategorikan sebagai hasil perikanan tinggi protein $(>50 \%)$ yaitu $70,34 \%$ dan rendah lemak $(<5 \%)$ yaitu $2,20 \%$ sehingga mengkonsumsi keong ini dapat mempertahankan asupan nutrisi seimbang yang kompatibel dengan diet rendah lemak.

Keong mata lembu merupakan sumber mineral yang berfungsi sebagai aprodisiak dan antioksidan diantaranya adalah $\mathrm{K}, \mathrm{Mg}, \mathrm{Ca}, \mathrm{Fe}$, $\mathrm{Zn}$, dan $\mathrm{Cu}$. Informasi dari kandungan gizi harus disampaikan ke nelayan setempat untuk memberikan gambaran dari nilai sumberdaya ini sehingga tindakan efektif dapat diambil untuk pemanfaatan yang tepat dari sumber daya gastropoda.

\section{Saran}

Saran yang dapat diberikan dari hasil penelitian ini adalah bahwa keong ini dikonsumsi dalam bentuk rebus dan sate maka perlu dilakukan penelitian mengenai pengaruh perebusan dan pengolahan terhadap kandungan gizinya.

\section{DAFTAR PUSTAKA}

[AOAC] Association of Official Analytical Chemist. 2005. Official methods of analysis $(18$ Edn). Association of Official Analytical Chemist Inc. Mayland. USA.

Abulude FO, Lawal LO, Ehikhamen G, Adesanya WO, Ashafa SI. 2006. Chemical composition and functional properties of some prawns from the coastal area of Ondo State, Nigeria. Electron J Environ Agric Food Chem 5(1): 1235-1240.

Adebayo-Tayo BC, Ogunjobi AA. 2008. Comparative effects of oven drying and sundrying on the microbiological, proximate nutrient and mineral composition of Tympanotonus spp (periwinkle) and Crassostrea spp (oyster). Elect J Environ Agric Food Chem 7(4): 2856-2862. 
Ademolu KO, Idowu AB, Mafiana CF, Osinowo OA. 2004. Performance, proximate, and mineral analyses of African giant land snail (Archachatina marginata) fed different nitrogen sources. African J Biotechnol 3(8): 412-417.

Adeyeye A. Afolabi EO. 2004. Amino acids composition of three different type of land snails consumed in Nigeria. Food Chemistry. 85(4):535-539.

Almatsier S. 2003. Prinsip Dasar Ilmu Gizi. Jakarta (ID): PT.Gramedia Pustaka Utama.

Anand P, Chellaram C, Kumaran S, Shantini F. 2010. Biochemical composition and antioxidant activity of Pleuroploca trapezium meat. Chem Pharm Res 2(4): 526-535.

Devanathan K, Srinivasan M, Periyasamy N, Balakrishnan S. 2011. Nutritional value of gastropod Babylonia spirata from Thazhanguda, Southeast Coast of India. Asn Pac J Tropic Biomedic 3(5):249252.

Ehgiator FAR, Oterai EA. 2012. Chemical composition and amino acid profile of a caridean prawn (Macrobrachium vallenhovenii) from Ovia River and tropical periwinkle (Tympanotonus fuscatus) from Benin River, Edo State, Nigeria. IJRRAS 11(1): 162-167.

Fagbuaro O, Oso JA, Edward JB, Ogunleye RF. 2006. Nutritional status of four species of giant land snails in Nigeria. $J$ Zhejiang University Sci B 7(9): 686-689. DOI: 10.1631/JZus.2006.130686.

Fahmi AS, Susanto E. 2012. Senyawa fungsional dari ikan: aplikasinya dalam pangan. $\quad$ Apl Teknol Pangan 1(4): 95-102.

FAO Fisheries and Aquaculture Department. 1992. The State Of World Fisheries and Aquaculture 2006. FOOD and Agriculture Organization of the United Nations. Electronic Publishing Policy and Support Branch, Rome. ISSN 10205489.

Goguklu N, Yerlikaya P, Cengiz E. 2004. Effects of cooking method on the proximate composition and mineral contents of rainbow trout (Oncorhynchus mykiss). Food Chem 84: 9-12. DOI: 10.1016/S0308-8146(03)00161-4.

Hafiluddin, Nurjanah, Nurhayati T. 2011. Kandungan gizi dan karakterisasi senyawa bioaktif lintah laut (Discodoris sp.). JIPK 3(1):1-6.

Kagawa Y. 1999. 4th Amanded Japaness Food Content Tables, 485-486. Di dalam: Okuzumi M dan Fujii T, editor. 2000. Nutritional and Functional Properties of Squid and Cuttlefish. Tokyo: Natioanl Cooperative Assosiation of Squid Processor.

Karppanen H, Karppanen P, Mervaala E. 2005. Why and how to implement sodium, potassium, calcium, and magnesium changes in food items and diets. $J$ of Human Hypertension 19: S10-S19. DOI: 10.1038/SJ.Jhh.1001955.

Larsen R, Eilersten KE, Elvevoll EO. 2011. Health benefits of marine foods and ingredients. Biotechnology Advaces 29:508-518. DOI: 10.1016/J.Biotechadv.2011.05.017.

Majewska D, Jakubowska M, Ligocki M, Tarasewicz Z, Szczerbin D, Karamucki T, Sales J. 2009. Physicochemical characteristics, proximate analysis and mineral composition of ostrich meat as influenced by muscle. Food Chem 117: 207-211.

DOI: 10.1016/J.FoodChem.2009.03.100.

Milinsk MC, Padre RdG, Hayashi C, de Souza NE, Matsushita M. 2003. Influence of diets enriched with different vegetable oils on the fatty acid profiles of snail Helix aspersa maxima. Food Chem 82(4): 553-558. DOI: 10.1016/S03088146(03)00010-4. 
Muchtadi D. 2009. Pengantar Ilmu Gizi. Bandung (ID): CV. Alfabeta. hlm.20-56.

Nurjanah, Zulhamsyah, Kustiyariyah. 2005. Kandungan mineral dan proksimat kerang darah (Anadara granosa) yang diambil dari Kabupaten Boalemo, Gorontalo. BTHP. 7(2): 15-24.

Palpandi C, Vairamani S, Shanmugam A. 2010. Proximate composition and fatty acid profile of different tissues of the marine neogastropod Cymbium melo (Solander, 1786). Ind J Fish 57(3):35-39.

Periyasamy N, Srinivasan M, Devanathan K, Balakrishnan S. 2011. Nutritional value of gastropod Babylonia spirata (Linnaeus, 1758) from Thazhanguda, Southeast coast of India. Asn Pac J Trop Biomedic S249-S252.

Primadhani. 2006. Konsumsi energi dan protein pada penderita penyakit hati rawat inap di Perjan RS. DR. Cipto Mangunkusumo Jakarta [Skripsi]. Bogor: Fakultas Pertanian, Institut Pertanian Bogor.

Qunfang Z, Guibin J, Zhongyang L, Lina L, Chungong Y, Yongning W. 2004. Survey of butyltin compounds in 12 types of foods collected in China. Food Additives and Contaminants 21(12): 1162-1167. DOI: $10.1080 / 02652030400019364$.

Rink L dan Kirchner H. 2000. Zinc-altered immune function and cytokine production. Nutr Suppl 130: 1407S1411S.

Royani DS, Hardjito L, Santoso J. 2007. Penapisan inhibitor topoisomerase I dan komposisi kimia dari siput laut Nerita albicilla. JPP. 10(1): 42-46.

Sioen I, Van Camp J, Verdonck F, Verbeke W, Vanhonacker F, Willems J, Stefaan DH. 2008. Probabilistic intake assessment of multiple compounds as a tool to quantify the nutritional-toxicological conflict related to seafood consumption.
Chemosphere 71(6): 1056-1066. DOI: 10.1016/J.Chemosphere.2007.11.025.

Soekendarsi E. 2004. Biologi reproduksi dan upaya pemijahan keong mata lembu Turbo argyrostoma Linnaeus 1758 [Disertasi]. Bogor: Program Pascasarjana, Institut Pertanian Bogor.

Suzuki T. 2004. Karakteristik Nutrisi Produk Perikanan. ICA/ICFO/IKPI Seminar for Promotion of Sustainable Development of Fisheries in Indonesia. Hotel Aryaduta 16-19 Maret. Jakarta.

Udoh AP, Akpanyung EO, Igiran IE. 1995. Nutrients and anti-nutrients in small snails (Limicolaria aurora). Food Chem 53(3):239-241.

Waranmaselembun C. Hardjito L, Baskoro MS. 2007. Penapisan inhibitor topoisomerase I dan komposisi kimia dari kerang laut Atactodea striata. JPP. 10(1): 32-36.

World Health Organization. 1989. Heavy Metals-Environmental Aspects. Environment Health Criteria. No. 85. Geneva, Switzerland.

Winarsi H. 2004. Respon hormonal dan imunitas wanita premonopause terhadap minuman fungsional berbahan dasar susu skim yang disuplementasi dengan isoflavon kedelai dan $\mathrm{Zn}$ [Disertasi]. Bogor: Sekolah Pascasarjana, Institut Pertanian Bogor.

Witjaksono HT. 2005. Komposisi kimia ekstrak dan minyak dari lintah laut (Discodoris boholensis) [tesis]. Bogor: Sekolah Pascasarjana, Institut Pertanian Bogor.

Xie SH, Wang Z, Xu SY. 2007. Characteristics of Bellamya purificata snail foot protein and enzymatic hydrolysates. Food Chem 101(3): 1188-1196. DOI: 10.1016/J.FoodChem.2006.03.031. 